\title{
Work profile and associated health hazards among nursing students at Mansoura University, Egypt
}

\author{
Hala S. Abou-Elwafa ', Eman O. Khashaba ', Abdel-Hady El-Gilany² and Samar Abd El-Raouf ${ }^{3}$
}

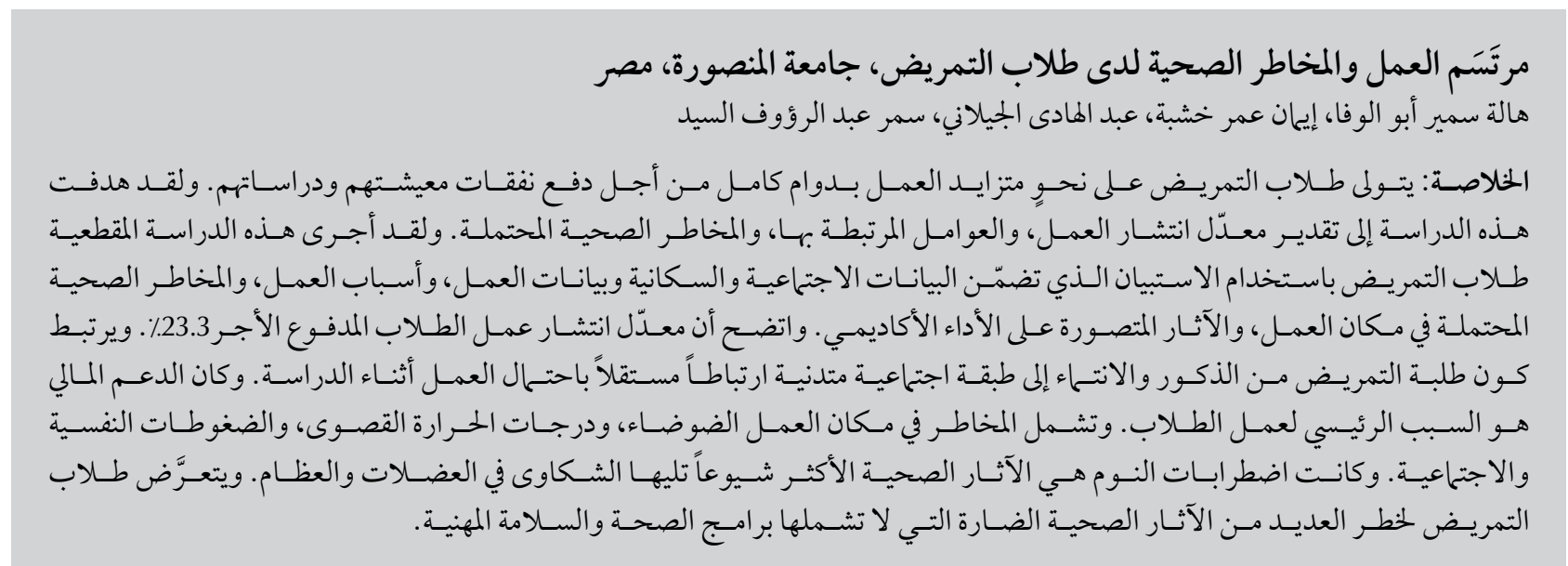

ABSTRACT Nursing students are increasingly undertaking paid term-time employment to finance their living expenses and studies. The objectives of this study are to estimate its prevalence, factors associated, and possible health hazards. A cross-sectional study was conducted of nursing students using a questionnaire that included sociodemographic and employment data, reasons for working, possible health hazards in the workplace, and perceived effects on academic performance. The prevalence of student paid employment was found to be 23.3\%. Being male and belonging to a low social class were independently associated with the likelihood of working while studying. Financial support was the main reason for student employment. Workplace hazards included noise, temperature extremes and psychosocial stressors. Sleep disorders were the most frequent health effects followed by musculoskeletal complaints. Nursing students are at risk from many deleterious health effects which are not covered by occupational health and safety programmes.

\section{Profil professionnel et risques sanitaires associés parmi les étudiants en soins infirmiers de l'Université de Mansoura, Égypte}

RÉSUMÉ Les étudiants en soins infirmiers sont de plus en plus nombreux à avoir un activité rémunérée durant l'année universitaire dans le but de subvenir à leurs besoins et de financer leurs études. La présente étude a pour objectif d'estimer la prévalence de ce type d'activité, les facteurs et les risques sanitaires qui y sont associés. Une étude transversale a été conduite auprès d'étudiants en soins infirmiers à l'aide d'un questionnaire incluant des données socio-démographiques et sur l'emploi, les raisons de travailler, les risques sanitaires possibles sur le lieu de travail, et les conséquences perçues sur les performances universitaires. La prévalence des emplois étudiants rémunérés a été estimée à $23,3 \%$. Le fait d'être de sexe masculin et l'appartenance à une classe sociale basse avaient une association indépendante avec la probabilité de travailler pendant les études. Un besoin de soutien financier était la raison principale de l'emploi étudiant. Les risques sur le lieu de travail incluaient le bruit, des températures extrêmes et des facteurs de stress psychologiques. Les conséquences sur la santé les plus fréquentes étaient des troubles du sommeil, suivis par des douleurs musculosquelettiques. Les étudiants en soins infirmiers sont exposés à des risques nocifs pour la santé qui ne sont pas pris en compte par les programmes de santé et de sécurité au travail.

${ }^{'}$ Department of Occupational Health and Industrial Medicine, Faculty of Medicine, Mansoura University, Mansoura, Egypt (Correspondence to: E.O. Khashaba: eman_khashaba2000@yahoo.com). ${ }^{2}$ Department of Public Health, Faculty of Medicine, Mansoura University, Egypt. ${ }^{3}$ Department of Community Health Nursing, Faculty of Nursing, Mansoura University, Mansoura, Egypt.

Received: 04/09/15; accepted: 22/05/16 


\section{Introduction}

Student employment is increasingly found in many countries. Not only do more students work but they also work for longer hours compared to earlier decades (1). Most countries in Western Europe and North America have experienced an increase in student employment. A recent Europe-wide student survey showed that in some countries more than two-thirds of students are employed and their income from employment covers up to $80 \%$ of their living and study costs (2). The average student employment rate is around $47 \%$ in Europe (1).

Several reasons explain why students get employed such as increasing costs of higher education and changes in the funding system (3), changes in the expected lifestyle and consumption preferences of students (4). Also, the profile of university students has changed as higher education is now more open to students who are more inclined to work during their studies (5) and, finally, universities may now provide opportunities that make combining work and study more feasible (1).

An excessive work load on students may compromise their academic progress. Less study time is associated with lower learning outcomes and a higher probability of dropping out of school $(5,6)$. At the same time, students may work also for positive benefits. Employment may provide necessary work experience and contribute to building a social network that will help find a job in the future (7).

Nursing students are increasingly undertaking paid term-time employment to finance their living expenses and studies (8). Apart from the possible adverse impact on academic progress, nursing workers in hospitals are exposed to different occupational risk factors, including exposure to chemical substances, which can be inhaled or come in contact with the skin, causing deleterious health effects (9).

To the best our knowledge, there has been little research on undergraduate employment among nursing students in developing countries including Egypt. Therefore, the objectives of this study were to estimate the prevalence of employment among undergraduate nursing students in Mansoura University, and to assess the factors associated with taking up work and the possible occupational health and safety hazards of working.

\section{Methods}

\section{Study design and setting}

A descriptive cross-sectional study was carried out on undergraduate nursing students in Mansoura University during the academic year 2013-2014.

\section{Sample size and selection}

Pre-university education for the studied students included a 2-year programme (Technical Nursing Institute or Health Technical Institute-Nursing Section). All students in all academic years were targeted except first-year students who were excluded as they had no experience of work. The total target population was 1846 students (including first-year students). The male to female ratio was 1:3, after exclusion of first-year students. A pilot study was conducted on 100 students (not included in the final study) which found that about $23 \%$ had worked at some point in their past academic years.

Sample size was calculated according to the following equation (10): $n=Z^{2} \mathrm{P}(1-\mathrm{P}) / \mathrm{d}^{2}$, where $n=$ sample size, $Z=Z$ statistic for $95 \%$ confidence level (1.96), $P=$ expected prevalence (proportion) (23\%), and $d=$ precision (0.05). The required sample size was found to be 272. To compensate for non-responders, the sample size was increased by $20 \%$ and rounded to 330 students.
A stratified random sampling was used proportional to size according to the total number of students in each academic year (1087 after exclusion of all first year students): second year (560 students, 51.5\%), third year (306 students, 28.2\%) and fourth year (221 students, 20.3\%) of the total. Accordingly, the sample was distributed proportionately as follows: second year (170), third year (93), and fourth year (67) students. Students were recruited by systematic random sampling within each year group according to available student records with a random start then selection of every third student. This led to a total of 352 questionnaires being distributed and 330 questionnaires were returned with a response rate of $93.8 \%$.

\section{Data collection tool}

A self-administered semi-structured questionnaire in Arabic was used for data collection. It included the following information: demographic data, e.g. age, sex, residence, socioeconomic status of the family (11); paid employment information, e.g. working status, age of starting ever work, nature and place of work, the number of work hours per day; reasons for working; possible hazards at the workplace, e.g. physical (noise/vibration/temperature extremes, ionizing radiation, lifting heavy weights), biological, chemical products, which may include disinfectants, antiseptics, hazardous drugs and latex exposure, e.g. chlorine, glutaraldehyde, ethylene oxide and cytotoxic drugs, and psychosocial; perceived adverse health effects, e.g. musculoskeletal disorders, sleep disorders, occupational accidents or injuries; pre-employment health and safety training; and perceived effects on academic performance.

The content validity of the questionnaire was evaluated by a jury of 5 occupational medicine staff and the necessary changes were made before pilot testing. 
The questionnaires were distributed to the target students during a suitable break between the rounds (clinical training rounds related to nursing courses at different departments of Mansoura University Hospital) and before lectures under the supervision of one of the investigators to encourage participation and answer their enquiries. Each questionnaire required 10-15 minutes to complete.

\section{Ethical considerations}

The study was approved by the Research Ethics Committee of the Faculty of Nursing and Faculty of Medicine of Mansoura University, code number [R/15.12.85].

Informed verbal consent of the individuals to participate in the study was obtained before distribution of the questionnaire. All participants were assured of the confidentiality and anonymity of the data. Subjects participated voluntarily with a full right to withdraw from the study at any time.

\section{Data analysis}

Data were analysed using the SPSS, version 16 and Epi Info, version 7. Categorical variables are presented as numbers and percentages; the chisquared test was used for comparison between groups. Quantitative variables are presented as means and standard deviations (SD). Binary stepwise logistic regression analysis was used to determine the independent predictors of student employment as the dichotomous outcome variable. Variable found statistically significant in a bivariate analysis were entered into the logistic regression analysis using a forward Wald method. Odds ratios (ORs) and their $95 \%$ confidence intervals (CIs) were calculated. A $P$-value $\leq 0.05$ was considered to be statistically significant.

\section{Results}

The age of the sample of nursing students ranged from 19 to 22 years with a mean age 20.3 (SD 0.8) years. The overall prevalence of student employment was $23.3 \%$ (Table 1 ). Table 1 shows the sociodemographic characteristics of the students and their association with student employment. Student employment was significantly higher among male students, those whose fathers had received less than secondary education or worked in non-professional jobs and those and of very low socioeconomic status. Student employment was also significantly lower among second-year students compared to fourth-year students.

Logistic regression analysis showed that being male $(\mathrm{OR}=2.6$; $95 \% \mathrm{CI}$ : $1.44-5.05$ ) and belonging to a family of a very low socioeconomic status (OR $=2.8$; $95 \%$ CI: $1.34-5.82)$ were independently associated with employment while studying. On the other hand, second-year students were significantly less likely to be working $(\mathrm{OR}=0.3$; 95\% CI: 0.16-0.62) (Table 2). Father's occupation and education were not significant in the logistic regression and were excluded from the final regression analysis of independent variables associated with employment while studying.

Table 3 shows that more than half of the working students started work when they were older than 18 years and the majority worked in the field of nursing. Working students reported that the hospital was the most common place of work $(57.1 \%)$ and $38.9 \%$ worked shifts. The main reason for working while studying was for financial (68.8\%) but $54.5 \%$ also said they worked to gain experience. More than half of the working students (61.1\%) worked 8 hours or more daily and $63.6 \%$ had worked for less than 6 months in the past year.

Noise and temperature extremes were the most frequently reported physical hazards ( $84.4 \%$ and $80.5 \%$ respectively). Only $33.7 \%$ of the working students reported exposure to chemical hazards at work while a large per cent $(80.5 \%)$ mentioned exposure to workplace psychosocial stressors. Lack of safety training programmes and protective equipment at work were each reported by $68.8 \%$ of the working students. There was higher frequency of occupational health hazards among the students who started work after 18 years of age compared to those who started at a younger age; however, the difference was not statistically significant $(P>$ 0.05) (Table 4).

Working students reported that sleep disorders were the most frequent work-related health effects $(85.7 \%)$ followed by musculoskeletal complaints (74.0\%) with the most frequent sites being the legs/feet and back. Occupational injuries represented $68.8 \%$ of the reported work-related health effects, mostly needle-stick injuries (45.5\%) and $32.5 \%$ reported having occupational infections, mainly of the respiratory tract (Table 5).

Work-related health effects among students who started work after the age of 18 years were more frequently reported than that in younger age groups, but these were not statistically significant $(P>0.05)$. However, both musculoskeletal complaints and occupational injuries were more frequently reported among female students $(75.4 \%, 71.7 \%$ respectively) compared to male students $(24.6 \%, 28.3 \%$ respectively) with statistically significant difference $(P=$ $0.0006, P=0.01$ respectively) (Table 6).

It was found that $15.6 \%$ of the working students reported non-attendance of lectures and clinical training due to work load. Also, $17 \%$ reported rare attendance or non-attendance. More than half (54.5\%) of the working students considered work had a positive effect on their academic performance (Table 7).

\section{Discussion}

The prevalence of student employment was $23.3 \%$ among nursing students in our study with the percentage of employed students increasing across the academic years $(17.1 \%, 25.8 \%, 35.8 \%$ 


\begin{tabular}{|c|c|c|c|c|}
\hline Sociodemographic characteristic & $\begin{array}{l}\text { Total } \\
\text { No. }\end{array}$ & $\begin{array}{c}\text { Working student } \\
\text { No. (\%) }\end{array}$ & Significance test & OR $(95 \% \mathrm{Cl})$ \\
\hline Overall & 330 & $77(23.3)$ & & $(19.00-28.22)$ \\
\hline \multicolumn{5}{|l|}{ Sex } \\
\hline Man & 69 & $29(42.0)$ & $\chi 2=15.7, P \leq 0.001$ & $3.2(1.75-5.96)$ \\
\hline Women (R) & 261 & $48(18.4)$ & & 1 \\
\hline \multicolumn{5}{|l|}{ Academic year } \\
\hline Second & 170 & $29(17.1)$ & $\chi 2=9.7, P=0.001$ & $0.44(0.23-0.86)$ \\
\hline Third & 93 & $24(25.8)$ & $\chi 2=1.9, P=0.17$ & $0.73(0.37-1.45)$ \\
\hline Fourth (R) & 67 & $24(35.8)$ & & 1 \\
\hline \multicolumn{5}{|l|}{ Pre-university education } \\
\hline General secondary school & 167 & $39(23.4)$ & $\chi 2=0.3, P=0.5$ & $1.19(0.65-2.19)$ \\
\hline Nursing school & 40 & $13(32.5)$ & $\chi 2=2.5, P=0.1$ & $1.89(0.79-4.48)$ \\
\hline Health/nursing institute $(\mathrm{R})$ & 123 & $25(20.3)$ & & 1 \\
\hline \multicolumn{5}{|l|}{ Residence } \\
\hline Urban & 89 & $21(23.6)$ & $\chi 2=0.01, P=0.9$ & $1.02(0.55-1.88)$ \\
\hline Rural (R) & 241 & $56(23.2)$ & & 1 \\
\hline \multicolumn{5}{|l|}{ Father's education } \\
\hline$<$ Secondary school & 79 & $24(30.4)$ & $\chi 2=4.3, P=0.03$ & $1.98(1.01-4.00)$ \\
\hline Secondary school & 118 & $29(24.6)$ & $\chi 2=1.6, P=0.2$ & $1.48(0.77-2.84)$ \\
\hline > Secondary school (R) & 133 & $24(18.0)$ & & 1 \\
\hline \multicolumn{5}{|l|}{ Father's occupation } \\
\hline Non-professional ${ }^{1}$ & 110 & $33(30.0)$ & $\chi 2=4.1, P=0.04$ & $1.7(1.01-3.00 \geq)$ \\
\hline Professional/semiprofessional (R) & 220 & $44(20.0)$ & & 1 \\
\hline \multicolumn{5}{|l|}{ Mother's education } \\
\hline$<$ Secondary school & 84 & $20(23.8)$ & $\chi 2=0.4, P=0.4$ & $1.28(0.65-2.73)$ \\
\hline Secondary school & 144 & $37(25.7)$ & $\chi 2=1.2, P=0.2$ & $1.42(0.73-2.75)$ \\
\hline$>$ Secondary school $(\mathrm{R})$ & 102 & $20(19.6)$ & & 1 \\
\hline \multicolumn{5}{|l|}{ Mother's occupation } \\
\hline Working & 125 & $24(19.2)$ & $\chi 2=1.9, P=0.16$ & $0.68(0.38-1.21)$ \\
\hline Not working (R) & 205 & $53(25.9)$ & & 1 \\
\hline \multicolumn{5}{|l|}{ Family size } \\
\hline$\geq 5$ members & 259 & $56(21.6)$ & $\chi 2=1.9, P=0.16$ & $0.66(0.33-1.24)$ \\
\hline$<5$ members $(\mathrm{R})$ & 71 & $21(29.6)$ & & 1 \\
\hline \multicolumn{5}{|l|}{ Family income } \\
\hline Just met routine expenses & 104 & $26(25.0)$ & $\chi 2=0.01, P=0.9$ & $1.04(0.54-2.16)$ \\
\hline $\begin{array}{l}\text { Met routine \& emergency } \\
\text { expenses }\end{array}$ & 148 & $32(21.6)$ & $\chi 2=0.2, P=0.63$ & $0.86(0.43-1.72)$ \\
\hline Able to save money $(\mathrm{R})$ & 78 & $19(24.4)$ & & 1 \\
\hline \multicolumn{5}{|l|}{ Socioeconomic status } \\
\hline Very low & 90 & $32(35.6)$ & $\chi 2=3.8, P=0.04$ & $1.96(1.01-4.12)$ \\
\hline Low & 75 & $16(21.3)$ & $\chi 2=0.01, P=0.9$ & $0.96(0.42-2.22)$ \\
\hline Middle & 83 & $11(13.3)$ & $\chi 2=2.1, P=0.14$ & $0.54(0.22-1.32)$ \\
\hline $\operatorname{High}(R)$ & 82 & $18(22.0)$ & & 1 \\
\hline
\end{tabular}

${ }^{\prime}$ Non-professional includes trade and business $(n=14)$ and non-working $(n=6)$ and manual workers $(n=90)$.

$R=$ reference group; $O R=$ odds ratio; $C I=$ confidence interval. 


\begin{tabular}{|c|c|c|c|}
\hline Predictor & $\beta$ & $P$-value & Adjusted OR $(95 \% \mathrm{CI})^{1}$ \\
\hline \multicolumn{4}{|l|}{ Academic year } \\
\hline Second year & -1.15 & 0.001 & $0.3(0.16-0.62)$ \\
\hline Third year & -0.6 & 0.07 & $0.5(0.24-1.07)$ \\
\hline Fourth year $(\mathrm{R})$ & - & - & - \\
\hline \multicolumn{4}{|l|}{ Socioeconomic status } \\
\hline Very low & 1.03 & 0.006 & $2.8(1.34-5.82)$ \\
\hline Low & 0.43 & 0.3 & $1.5(0.68-3.51)$ \\
\hline Middle & -0.15 & 0.7 & $0.86(0.36-2.00)$ \\
\hline Higher (R) & - & - & - \\
\hline \multicolumn{4}{|l|}{ Sex } \\
\hline Male & 0.9 & 0.002 & $2.6(1.44-5.05)$ \\
\hline Female (R) & - & - & - \\
\hline Constant & - & -1.09 & - \\
\hline Per cent correctly predicted & - & 75.5 & - \\
\hline Model $\chi^{2}$ & - & $31.5 ; P \leq 0.001$ & - \\
\hline
\end{tabular}

${ }^{'}$ Adjusted for all variables found to be significant in the bivariate analysis.

$R=$ reference group $; O R=$ odds ratio; $C I=$ confidence interval.

for second, third, and fourth years respectively). About $91 \%$ of working students were engaged in paid and nursing-related work.

Our findings concur with other studies that employment among students increases with years of study although the proportion of working students is less among our sample. For example, survey data from 2496 students in Estonian public and private universities showed that term-time employment was extremely wide-spread among Estonian students and $61 \%$ of full-time students worked (1). The survey results also showed that the most important predictor for working was age. Older students (over 23 years) were more than three times more likely to have paid jobs than younger students. It is thus clear that when students are older they are more likely to have jobs and they work more on full-time jobs. Students do not wait until they finish their studies before they enter the labour market.

Similarly, in a study of nursing students in metropolitan Sydney, Australia there was a statistically significant increase in the percentage of students engaging in paid work during term time, increasing from $70 \%$ in Year 1 to $84 \%$ in Year 3 and a statistically significant difference was seen in the type of work undertaken, from non-nursing to nursing-related work (12).

In a survey of a second-year cohort of nursing students from a regional university in Australia, more than three-quarters (78\%) of students were participating in paid employment. This high number was anticipated because clinical facilities specifically recruit students at the end of the first year of their Bachelor of Nursing programme to work as assistants in nursing or enrolled nurses (13).

The lower proportion of students working in our study may be due to the Egyptian culture where among moderate or high socioeconomic levels, students depend on their families during study years, which may be similar to some western countries.

In our study, student employment was significantly higher among males while there was no statistically significant difference regarding urban/ rural residence. The survey of Estonian students revealed that personal characteristics did not seem to be influential in whether students worked (1). Our findings are different from those reported in a study of full-time undergraduate students at the University of Glasgow, Scotland where there was no significant difference between the proportion of male and female students who worked, however, significantly more students who lived at home worked compared to those who lived away (14). This could be explained by the cultural and social norms of Egypt in which males can move about more easily and are free to work while females are more conservative and tend to stay at home after study time.

Despite the fact that undergraduate education is free of charge in Egypt, the main reason for work while studying was for financial support (68.8\%); more additional money for personal needs and more than one reason were mentioned by the participants. This is supported by the fact that student employment in our study was more common among students from families of low socioeconomic status. This is similar to the results of the study in Estonia which found that the less the means of a family the more likely it was that a student worked 


\section{Table 3 Occupational profile of working students} Occupational profile

Ever working students

$(n=77)$

No. $(\%)$

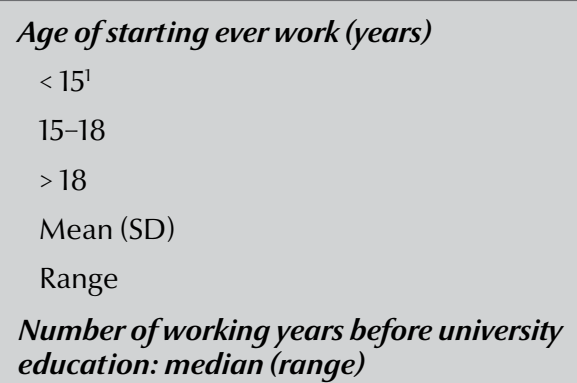

$9(11.7)$

26 (33.8)

$42(54.5)$

$18.3(2.2)$

12-20

$1(0.5-6)$

Field of work $(n=71)^{2}$

Nursing related

$65(91.5)$

Non-nursing related

Both

$70(90.9)$

Paid

Voluntary/unpaid

$12(15.6)$

Private clinic

Hospital

Other (pharmacy, store)

Morning

Evening

$30(38.9)$

Shift

During summer

Throughout the year

53 (68.8)

Financial support for own needs $s^{4}$

Gain practical experience

9 (11.7)

Cooperation with different medical teams

$17(22.1)$

Guarantee employment opportunity

$<8$

$\geq 8$

$10.3(3.1)$

Mean (SD)

$49(63.6)$

$<6$

$28(36.4)$

Below the legal age of working.

${ }^{2}$ Some respondents did not answer this question.

${ }^{3}$ Categories are not mutually exclusive.

${ }^{4}$ Own needs include smoking, accessories and entertainment.

$S D=$ standard deviation

in order to be able to support himself or herself (1). They found that while $77 \%$ of students from the low-income group worked for subsistence, only $62 \%$ of the middle-income group and $42 \%$ of the upper-income group reported this as a reason. Students from more affluent families were more likely to work for extra income and for general and professional work experience (1). Also, the study of full-time undergraduate students at the University of Glasgow reported that students noted financial necessity, extra cash for fun and work experience as the most important reasons for working (14). A study in Australia in 2011 found that students work to support their lifestyle (15).

Apart from the financial benefits, students have reported greater self-confidence, an understanding of the business world and skills development as benefits of paid work $(16,17)$. Students also perceive paid work will enhance their opportunities for full-time employment on leaving university (18), thus making them more 'employable' (19). In addition to providing a source of financial support while completing their nursing education (8), engaging in nursing-related work during the term time has been suggested to improve the "work-readiness" of these students in preparation for graduate practice through the development of personal and professional skills in clinical practice (16).

In our study, the mean number of work hours per day was 10.3. Much longer working hours were reported in other countries. In the study of full-time undergraduate University of Glasgow students, the mean number of hours worked was 14.2 (14). Similarly, the survey of 267 nursing students from a regional university in Australia reported that the average hours spent in paid employment were $14.43(\mathrm{SD}=10.50)$ hours per week (13).

In our study, the majority of working students were engaged in nursingrelated fields with only 5.6\% working in non-nursing related field. This agrees with the survey of a second year cohort of nursing students from a regional university in Australia, where the majority of students were engaging in nursingrelated work (13). 


\begin{tabular}{|c|c|c|c|c|c|}
\hline \multirow[t]{3}{*}{ Occupational health hazards } & \multirow{3}{*}{$\begin{array}{c}\text { Working } \\
\text { students } \\
(n=77) \\
\text { No. }(\%)\end{array}$} & \multicolumn{3}{|c|}{ Age at starting work (years) } & \multirow[t]{3}{*}{$P$-value } \\
\hline & & $\begin{array}{l}<15 \\
(n=9)\end{array}$ & $\begin{array}{c}15-18 \\
(n=26)\end{array}$ & $\begin{array}{c}>18 \\
(n=42)\end{array}$ & \\
\hline & & No. (\%) & No. (\%) & No. (\%) & \\
\hline \multicolumn{6}{|l|}{ Physical hazards' } \\
\hline Noise & $65(84.4)$ & $7(10.8)$ & $22(33.8)$ & $36(55.4)$ & 0.8 \\
\hline Temperature extremes & $62(80.5)$ & $8(12.9)$ & $20(32.3)$ & $34(54.8)$ & 0.7 \\
\hline Vibration & $32(41.5)$ & $3(9.4)$ & $11(34.4)$ & $18(56.3)$ & 0.8 \\
\hline Radiation & $24(31.2)$ & $3(12.5)$ & $8(33.3)$ & $13(54.2)$ & 0.9 \\
\hline Carrying heavy loads & $41(53.2)$ & $4(9.8)$ & $15(36.6)$ & $22(53.6)$ & 0.8 \\
\hline Chemical hazards & $26(33.7)$ & $3(11.5)$ & $9(34.6)$ & $14(53.7)$ & 0.9 \\
\hline Psychosocial stressors & $62(80.5)$ & $6(9.7)$ & $20(32.3)$ & $36(58.1)$ & 0.3 \\
\hline Lack of safety training programme & $53(68.8)$ & $7(13.2)$ & $18(34)$ & $28(52.8)$ & 0.8 \\
\hline Lack of PPE at work & $53(68.8)$ & $5(9.4)$ & $20(37.7)$ & $28(52.8)$ & 0.4 \\
\hline
\end{tabular}

${ }^{\prime}$ Categories are not mutually exclusive.

$P P E=$ personal protective equipment .

Our study showed that subjective noise and temperature extremes were the most frequently reported physical hazards by working students ( $84.4 \%$ and $80.5 \%$; respectively). In a study of daytime decibel levels in 4 medical/ surgical nursing units in hospital, it was found that noise levels in patient rooms were significantly higher than in the nurses' station and patient care areas were as noisy as a busy office. However, nurses' judgment of noise levels was not enough to make informed decisions for controlling the acoustic hospital environment (20).

In our study, $33.7 \%$ of working students reported exposure to chemical hazards at work. In a study of nurses at the emergency care unit of a university hospital in Brazil, participants confirmed they came in contact with different chemical compounds in their

\begin{tabular}{lc}
\hline $\begin{array}{l}\text { Table } 5 \text { Frequency of reported work-related health effects among working } \\
\text { students }\end{array}$ & Working students $(\boldsymbol{n}=\mathbf{7 7})$ \\
Work-related health effects ${ }^{1}$ & No. $(\%)$ \\
Musculoskeletal complaints & $57(74.0)$ \\
Neck & $15(19.5)$ \\
Arm/hand & $14(18.2)$ \\
Back & $36(46.8)$ \\
Leg/feet & $43(55.8)$ \\
Sleep disorders & $66(85.7)$ \\
Occupational injuries & $53(68.8)$ \\
Needle sticks & $35(45.5)$ \\
Fractures & $3(3.9)$ \\
Sprains & $11(14.3)$ \\
Occupational infection & $25(32.5)$ \\
Eye and skin & $9(11.7)$ \\
Respiratory tract & $16(20.8)$ \\
Bloodborne & $5(6.5)$ \\
\hline
\end{tabular}

work environment and they indicated that occupational exposure to these substances can cause health problems (21).

In addition, our study showed that a large proportion of working students reported exposure to workplace psychosocial stressors $(80.5 \%)$. This is similar to the findings of a study of Canadian nurses where nurses were significantly more likely to say that most days at work were "quite a bit" or "extremely" stressful compared to other employed postsecondary-educated women (22).

Our results report subjective sleep quality complaints among $85.7 \%$ of the working student nurses, which may be attributed to the fact that about $40 \%$ worked shifts and also to the combination of work and studies. Young healthy nurses tolerated the first night shift exposure well, as judged by parameters related to quality of sleep. An increased sleep need during work days led to longer total sleep time, but did not lead to longer supplementary sleep episodes (23).

In our study, $74 \%$ of the working students had musculoskeletal complaints mostly in the legs/feet (55.8\%) and back (46.7\%), with a significantly higher frequency among female students. This 


\begin{tabular}{|c|c|c|c|c|c|c|c|}
\hline \multirow[t]{3}{*}{ Work-related health effects ${ }^{1}$} & \multicolumn{4}{|c|}{ Age (years) } & \multicolumn{3}{|c|}{ Sex } \\
\hline & $\begin{array}{c}<15 \\
(n=9)\end{array}$ & $\begin{array}{c}15-18 \\
(n=26)\end{array}$ & $\begin{array}{c}>18 \\
(n=42)\end{array}$ & $P$-value & $\begin{array}{c}\text { Male } \\
(n=29)\end{array}$ & $\begin{array}{l}\text { Female } \\
(n=48)\end{array}$ & $P$-value \\
\hline & No. (\%) & No. (\%) & No. $(\%)$ & & No. (\%) & No. (\%) & \\
\hline Musculoskeletal complaints $(n=57)$ & $6(10.5)$ & $20(35.1)$ & $31(54.4)$ & 0.8 & $14(24.6)$ & $43(75.4)$ & 0.0006 \\
\hline Sleep disorders $(n=66)$ & $8(12.1)$ & $22(33.3)$ & $36(54.5)$ & 0.9 & $22(33.3)$ & $44(66.7)$ & 0.056 \\
\hline Occupational injuries $(n=53)$ & $5(9.4)$ & $18(34.0)$ & $30(56.6)$ & 0.6 & $15(28.3)$ & $38(71.7)$ & 0.01 \\
\hline Occupational infection $(n=25)$ & $3(12.0)$ & $7(28.0)$ & $15(60.0)$ & 0.7 & $8(32.0)$ & $17(68.0)$ & 0.4 \\
\hline
\end{tabular}

${ }^{\prime}$ Categories are not mutually exclusive.

concurs with a study among Korean nursing students where musculoskeletal symptoms at any body site were reported by $73.3 \%$ of the participants. The most commonly reported sites were the shoulder (46.0\%), lower back (39.1\%), neck (35.6\%), feet (25.2\%) and lower legs (23.8\%) (24). It has been reported that women have a higher musculoskeletal morbidity than men (25). Greater prevalence or severity of symptoms may be due to the higher demands and constraints that women face or because women are more affected by, or vulnerable to, the health impact of particular demands and constraints (26).

A study at a public hospital in Brazil of occupational health hazards for intensive care unit nurses and nursing technicians reported that leg pain and sleep disturbance symptoms were at critical levels among nurses; among nursing technicians, critical levels were detected for leg and back pains (27).

It is widely accepted that the most common occupational hazard for all health care professionals involved in clinical care is needle-stick and sharps injuries mainly caused by inadequate disposal and recapping of needles (28). This concurs with our study where the most frequently reported occupational injuries among the working students were needle-sticks injuries (45.5\%). In addition, a study of the frequency and causes of occupational injuries among nursing students in Turkey reported that needle sticks (47.3\%) and broken ampoules during medication preparation (37.8\%) were the 2 most common reasons for injuries (29). Also, in a study of 124 nurses working in the emergency

\begin{tabular}{lcc}
\hline Table 7 Academic achievements of working nursing students & \\
\hline Academic performance $(\boldsymbol{n}=77)$ & No. & $\%$ \\
Previous year's score & 14 & 18.2 \\
$\quad$ Unsatisfactory' & 12 & 15.6 \\
Good & 51 & 66.2 \\
$\quad$ Very good & & \\
University attendance & 8 & 10.4 \\
Never & 5 & 6.5 \\
Rarely (once per week) & 18 & 23.4 \\
Average (twice per week) & 46 & 59.7 \\
Regular (daily) & 12 & 15.6 \\
$\quad$ Non-attendance due to work load & & \\
Effect of work on academic performance & 42 & 54.5 \\
Positive & 35 & 45.5 \\
$\quad$ Negative
\end{tabular}

'Unsatisfactory includes students who had repeated failure, postponed exams and a pass $(<60-65 \%)$ score.

departments of 6 general hospitals in Greece, $77.2 \%$ reported exposure to blood or body liquids through the skin due to needle-stick injury (28).

In our study, lack of safety training programmes and protective equipment at work were reported by $68.8 \%$ of working students. These findings suggest the need for the integration of occupational health and safety and practical training in the first year curricula with a focus on the prevention of needle-stick injuries and the effective use of personal protective equipment.

The results of our study showed that about $60 \%$ of the working students regularly attended university and more than half believed that working has a positive effect on their academic performance. Several studies have reported negative consequences of full-time students participating in paid work during termtime in higher education, which include higher stress levels (18), a reduction in leisure and social activities $(30,31)$, missing classes (32), and handing in assignments late (17).

As more nursing students are employed, it is essential that schools of nursing examine the relationship between student employment and academic performance. A statistically significant negative relationship was found between students working $>16$ hours a week and academic performance, especially in high-attrition courses (33).

There were some limitations to our study. The use of self-reports can be prone to error because nurses' reporting 
patterns could be influenced by their own knowledge of health conditions and risks. Also the possibility of recall bias cannot be excluded. Furthermore we could not directly assess the occupational health hazards (i.e. noise or vibration) in the multiple private sectors where the students work and evaluation depended only on the students' reports which could be subjective.

Further research is recommended for assessment of sleep disorders and needle stick injuries among working nursing students.

\section{Conclusion}

In conclusion, employment is common among nursing students in our university. As reported by the students, working has positive effects on both their education and experience despite having negative health consequences. It is necessary to put in place regulations to minimize the adverse health effects of student employment and to enforce child labour laws as $11.7 \%$ of the students started work below 15 years i.e. below the legal age of working in Egypt.
It is recommended to provide advice to all incoming and current students on working, perhaps producing a leaflet with information on how to minimize any adverse impact of part-time work on health and academic performance and how to maximize the benefits of working on student potential. It would be useful to implement occupational health and safety training during nursing education as many work-related health effects seem to be modifiable.

\section{Funding: None.}

Competing interests: None declared.

\section{References}

1. Beerkens M, Maügi E, Lill L. University studies as a side job: causes and consequences of massive student employment in Estonia. High Educ. 2011;61:679-92.

2. Social and economic conditions of student life in Europe: Synopsis of indicators, Final report, Eurostudent III 2005-2008. W. Bielefeld: Bertelsmann Verlag GmbH \& Co. KG; 2008. (http://www.felvi.hu/pub_bin/dload/eurostudent/Eurostudent_III.pdf,accessed25 February, 2017).

3. Survey of higher education students' attitudes to debt and term-time working and their impact on attainment. A report to Universities UK and HEFCE by CHERI and London South Bank University.London: Universities UK; 2005 (http://www. universitiesuk.ac.uk/policy-and-analysis/reports/Documents/2005/survey-higher-education\%20students-attitudesto-debt-term-time-work.pdf, accessed 25 February, 2017).

4. Penman S, McNeill L. Spending their way to adulthood: Consumption outside the nest. Young Consumers. 2008;9(3):15569.

5. Pascarella E, Terenzini P. Studying college students in the 21st century: Meeting new challenges. The Review of Higher Education. 1998;21(2):151-65.

6. Kuh G. The other curriculum: Out-of-class experiences associated with student learning and personal development. J Higher Educ. 1995;66(2):123-55.

7. Light A. In-school work experience and the returns to schooling. J Labor Econ. 2001;19(1):65-93.

8. Rochford C, Connolly M, Drennan J. Paid part-time employment and academic performance of undergraduate nursing students. Nurse Educ Today. 2009;29(6):601-6.

9. Bulhões I. Riscos do trabalho de enfermagem [Risks of nursing work]. Second ed. Rio de Janeiro (RJ): Folha Carioca; 1998.

10. Daniel W. Biostatistics: A foundation for analysis in the health sciences. 7th ed. New York: John Wiley \& Sons; 1999.

11. El-Gilany A, El-Wehady A, El-Wasify M. Updating and validation of the socioeconomic status scale for health research in Egypt. East Mediterr Health J. 2012;18(9):962-8.

12. Salamonson Y, Everett B, Koch J, Andrewd S, Davidson P. The impact of term-time paid work on academic performance in nursing students: A longitudinal study. Int J Nurs Stud. 2012;49:579-85.

13. Salamonson $Y$, Andrew S. Academic performance in nursing students: influence of part-time employment, age and ethnicity. J AdvNurs. 2006;55(3):342-51.
14. Smith N, Taylor P. 'Not for lipstick and lager'. Students and part time work, Scottish Affairs. 1999;28:147-164.

15. Polidano C, Zakirova R. Outcomes from combining work and tertiary study. Canberra: Commonwealth of Australia; 2011 (http://files.eric.ed.gov/fulltext/ED514723.pdf, accessed 24 February 2017).

16. Curtis S, Shani N. The effect of taking paid employment during term-time on students' academic studies. J Furth High Educ. 2002;26(2):129-38.

17. Robotham D. Combining study and employment: a step too far? Educ Train. 2009;51(4):322-32.

18. Mclnnis C, Hartley R. Managing study and work: the impact of full-time study and paid work on the undergraduate experience in Australian universities. Canberra: Commonwealth of Australis; 2002 (http://melbourne-cshe.unimelb. edu.au/_data/assets/pdf_file/0007/1669975/eip02_6. pdf,accessed24 February 2017).

19. Curtis S. Students' perceptions of the effects of term-time paid employment. Educ Train. 2007;49(5):380-90.

20. Pope D. Decibel levels and noise generators on four medical/ surgical nursing units. J ClinNurs. 2010;19(17-18):2463-70.

21. Xelegati R, Robazzi M, Marziale M, Haas V. Chemical occupational risks identified by nurses in a hospital environment. Rev Lat Am Enfermagem. 2006;14(2):214-9.

22. Ratner P, Sawatzky R. Health status, preventive behaviour and risk factors among female nurses. Health Rep. 2009;20(3):5361.

23. Fietze I, Knoop K, Glos M, Holzhausen M, Peter J, Penzel T. Effect of the first night shift period on sleep in young nurse students. Eur J Appl Physiol. 2009;107(6):707-14.

24. Smith DR, Choe MA, Chae YR, Jeong JS, Jeon MY, An GJ. Musculoskeletal symptoms among Korean nursing students. Contemp Nurse. 2005 Jul-Aug;19(1-2):151-60.

25. LeResche L. Gender considerations in the epidemiology of chronic pain. In: Crombie IK, Croft PR, Linton SJ, LeResche L, Von Korff M, editors. Epidemiology of pain. Seattle, USA: International Association for the Study of Pain; 1999. pp. 43-52.

26. McDonough $P$, Walters $V$. Gender and health: reassessing patterns and explanations. SocSci Med. 2001;52(4):547-59.

27. Shimizu H, Couto D, Merchán-Hamann E, Branco A. Occupational health hazards in ICU nursing staff. Nurs Res Pract.2010;2010:849169. doi: 10.1155/2010/849169. 
28. Gourni P, Polikandrioti M, Vasilopoulos G, Mpaltzi E, Gourni M. Occupational Exposure to blood and body fluids of nurses at Emergency department. Health Sci J. 2012;6(1)

29. Unver $\mathrm{V}$, Tastan S, Coskun H. The frequency and causes of occupational injuries among nursing students in Turkey. Arch Environ Occup Health. 2012;67(2):72-7.

30. Manthei R, Gilmore A. The effect of paid employment on university students' lives.Educ Train. 2005;47(3):202-15.
31. Hall R. The work-study relationship: experiences of full-time university students undertaking part-time employment. J Educ Work. 2010;23(5):439-49.

32. McKechnie J, Dunleavy K, Hobbs S. Student employment and its educational impact: a Scottish study. Scott Edu Rev. 2005;2005(37):1.

33. Reyes H, Hartin V, Loftin C, Davenport D, Carter V. The impact of employment on nursing students' academic performance. Nurse Educ. 2012;37(5):218-21. 